\title{
Overview of Some Basic Terms of Economy in Albanian Language in the Approach with English Language
}

\author{
Prof. Ass. Dr. Sadete Pllana \\ University of Prishtina "Hasan Prishtina" Faculty of Economics \\ Email: sadetepllana@outlook.com \\ Mr. Sc. Gani Plana, PhD Student \\ University of Prishtina "Hasan Prishtina" Faculty of Mechanical Engineering \\ Email: ganipllana44@gmail.com
}

\section{Doi:10.5901/ajis.2015.v4n3s1p65}

\begin{abstract}
In the new circumstances, at the beginning of the third millennium, in the impulsion of necessities of life and society, people of finance and economy professions created multiple terms, and this was done in the way of using English terminology relying on the nature of the Albanian language. But, despite the sensitive development and enrichment of the economy terminology, we notice the phenomenon of frequent borrowing; the use of foreign words for which there are relevant words in Albanian language, or were created before and new words can always be created. Mainly, the created circumstances gave rise to new concepts in the field of economy and enriched the terminology with suitable terms. In this paper we present the idea of formation, standardization and revision of several previously published terminologies in terminological dictionaries of economy and finance as well as their replacement with new terms.
\end{abstract}

Keywords: terminology, economics, finance, compound words, standardization.

\section{Prelude}

The history of Albanian terminology is seamlessly related to the whole history of the development of our language, as a written language and a language of culture. The real work for the enrichment of the Albanian language with word-terms begins with the Renaissance men ${ }^{1}$, who took over the difficult task of establishing the basis in Albanian terminology, proving through evidence that the Albanian language can become a culture language for the progression of the Albanian people.

Starting from the fact that Albanian terminology has remained still at the stage of identification; of albanianization of terminological units of every field of science, technology, informatics, economy and finance, diplomacy, and cultural production, ie. standardization phase, with the aim to become its unification, respectively its normative; permanent team work is required of specialists in narrow fields, and of linguists. Scientific works that have emerged to date by Albanian researchers ${ }^{2}$, are undoubtedly of a particular importance, but are not sufficient and much still remains to be done. But, because of the specificity and of the theoretical and practical achievements, today we can talk about a particular area of Albanian terminology and terminography, and, in this case also for the formation and standardization of the terminology of economy in Albanian language.

${ }^{1}$ L. Dodbiba, "Zhvillimi i terminologjisë gjuhësore shqipe nga Rilindja deri sot", në Konferenca e parë e studimeve albanologjike, Tiranë, 1965, f. 183-191.

${ }^{2}$ A. Duro, "Terminologjia si sistem", Tiranë, 2001; "Termi dhe fjala në gjuhën shqipe", Tiranë, 2009; H. Pasho, "Terminologjia e ekonomisë në gjuhën shqipe", Tiranë, 2005;M. Samara, "Rreth leksikut politik e shoqëror në gjuhën shqipe", Tiranë, 2008. Disa monografi të botuara dhe të hartuara nga A. Duro, V. Proko-Jazexhiu, S. Pllana, F. Leka, E. Lafe, H. Çipuri, E, Dashi, V. Dervishi, V. Bici, A. Hanxhari etj. ; disa përmbledhje studimesh; qindra studime e artikuj shkencorë të botuar në revistat shkencore në Shqipëri, Kosovë, Maqedoni e vende tjera në botë, të hartuara nga terminologë të njohur, si E. Çabej, L. Dodbiba, K. Ashta, F. Leka, H. Pasho, H. Çipuri, A. Duro, P. Nushi, V. Nuhiu, H. Gorani, Sh. Islamaj, S. Pllana, G. Pllana, A. Zymberi, A. Dika, N. Caka, L. Susuri, N. Rexha, Q. Murati, E. Stavileci, etj. 


\section{New Tasks for the Terminologists and the Terminology of Albanian Language in the Field of Economics}

The rapid development of global economy and the nowadays positive changes in the country, sets new tasks for the Albanian terminologists and terminology: with the induction of new terminology for areas of new concepts (such as computing, economics, diplomacy, sociology etc., as borrowed terms mostly from English, as well as Albanian or albanianized terms) and terminological changes. The new situation in terminology requires not only albanianization, unification and standardization by terminologists, (not only within the terminological field and by specialists of this narrow field), but also in its use in school, at university, in the media, in official communication etc.

The terminology reflects more directly the development and modernization of today's Albanian language itself and is closely related to the progress of education, science and culture, the economy and the industry, with the spread of modern scientific and technics knowledge across society.

The idea of reviewingsome of earlier published terminologies in previous Glossaries ${ }^{3}$, has support also from politics, social, economic and cultural changes in Albania, Kosovo and Macedonia, something which is inherent to all the changes in the lexical system, by reassessing also the native - foreign word rapport, by narrowing as much as possible the competitive cases of terminological units, of creating a database bank for terms of economy and finance especially in textbooks and scientific studies. Therefore, well prepared terminologists for the terminology of economics and finance are necessary, as well as the use of more advanced computer methods, with completed terminology centers, and terminologists from Albania, Kosovo as well as Macedonia, in order to move at the developmental pace in this field with other European countries.

\section{Terms which Nominate the Main Features and Notions of Economy and Finance}

In the third millennium, the new socio-economic system with its new notions and European laws conditioned the creation of a new terminological system that determines also the enrichment of existing dictionaries with new terms. The main notion, the notion of the new order, capitalism, which is the essence of this system, became linked with a range of economic and other notions, and, as a consequence, the number of terms - compound words is also relatively large. Below we will present just a few key terms - compound words, since their number is relatively large, which have become established and are most frequently used in economics and finance. Thus, with the term kapital-capitala large number of terms - compound words have been formed:

- kapital bazë-core capital, kapital fiks-fixed capital, kapital financiar-financial capital, kapital fizik-physical capital, kapital i bankës-bank capital, kapital i huazuar-loan capital, kapital i investuar-ventura capital, kapital $i$ jashtëm-outside capital, kapital i kompanisë-company capital, kapital i bllokuar-frozen capital, kapital i rrezikuar-risk capital, kapital i vdekur-unemployed capital, kapital kombëtar-capital stock of nation, kapital njerëzor-human capital, kapital qarkullues-circulating capital etj.

Further, we will present the basic notions bankë-bank, kontratë-contract, kamatë-interest, çek-check (US)-cheque , çmim-price, produkt-quality, pagesë-payment, that associate with a wide circle of economic problems, with main feature of this economy and include also a wide circle of terms like:

- bankë arkëtimi-collecting bank, bankë e depozitave-deposit bank, bankë e tregtisë së jashtme-foreign trade bankë, bankë jashtë vendit-offshore bank, bankë kombëtare-national bank, bankë kreditimi-credit bank, bankë kursimi-savings bank, bankë qendrore-central bank, bankë rajonale-regional bank, bankë shtetërore-state bank etj.;

- kontratë afatgjatë-long-term contract, kontratë afatshkurtër-short term contract, kontratë bazë-host contract, kontratë biznesi-business contract, kontratë blerje-buying contract, kontratë blerjeje-contract of purchase, kontratë dypalëshe-bilateral contract, kontratë e hapur-open-ended contract (open charter), kontratë e tregtisë së jashtme-foreign trade contracvt, kontratë eksportimi-export contract, kontratë furnizimi-supply contract, kontratë investimi-investment contract, kontratë kryesore-principal contract, kontratë lizingu-leasing contract, kontratë me vlerë minimale-minimal value contract, kontratë ndërtimi-constraction contract, kontratë për blerjepurchase contract, kontratë për licencë-licence contract, kontratë publike-public contract, kontratë punësimi-

${ }^{3} \mathrm{H}$. Gorani, "Fjalor i termave dhe i shprehjeve ekonomike serbokroatisht-shqip", Prishtinë, 1989. "Banking terminology (AlbanianEnglish-French-Italian-Russian)", Tirana, 2014. N. Rexha, "Fjalor i biznesit, ekonomikës dhe finances shqip-anglisht", ASAU, Prishtinë, 2009. 
contract of employment, kontratë qeveritare-governmental contract, kontratë shitblerjeje-contract of sale and purchase, kontratë shitjeje-sales contract, kontratë shtesë-additional contract, kontratë transport-contract of carriage etj;;

- kamatë e llogaritur-imputed interest, kamatë efektive-effective interest, kamatë kompensimi-compensatory interest etj.;

- çek i bardhë-blank check, çek i limituar-limited check, çek i vërtetuar-certifed check, çek i xhiruar-endorsed check, çek i zbuluar-bounced check etc.;

- çmim bazë-base price, çmim botëror-world price, çmim bruto-gross price, çmim eksporti-excport price, çmim fabrike-factory price, çmim fillestar-initial price, çmim fleksibil-flexible price, çmim i arit-gold price, çmim $i$ barabartë-parity price, çmim i blerjes, buying price, çmim i faturuar-invoiced price, çmim i fundit-bottom price, çmimi i kontrolluar-controlled price, çmim i ngritur-increased price, çmim i ofruar-offered price, çmim i prerëfixed price, çmim i shitjes-selling price, çmim i tregut-ruling price, çmim i ulur-reduced price, çmim konkurruescompetitive price, çmim me doganë-price inclusive duty, çmim me TVSH-price inclusive VAT, çmim neto-net price, çmim pa ambalazh-price excluding packaging, çmim për copë (ose njësi)-price per piece (or unit), çmim real-real price, çmim stinor-seasonal price etc.;

- produkt cilësie-quality product, produkt familjar-product family, produkt $i$ dëshirueshëm-desired product, produkt i gatshëm-finished product, produkt i ri-new product, produkt kombëtar bruto (GNP)-gross national product, produkt përfundimtar-final product etc.;

- pagesë e borxhit-payment of a debit, pagesë e kamatës (interesit)-payment of interest, pagesë e parakohshme-payment before due date, pagesë e pjesshme-partial payment, pagesë e plotë-payment in full, pagesë me çek-payment by cheque, pagesë me këste-payment by instalments, pagesë neto-net pay, pagesë plus-paid-in surplus, pagesë shtesë-supplementary payment, pagesë taksash-payment of duties, pagesë tatimore-tax payment etc.

Notions of specific economic laws: ligj i punës-labour law, ligj i tatimit mbi të ardhura-income tax code, ligj mbi tarifa-tariff law, ligj tatimor-tax law, ligj për mbrojtjen e mjedisit-environmental protection law, ligj i tregtisë ndërkombëtareinternational commercial law etc.

Notions in the field of trade: tregti botërore-wordl trade, tregti detare-sea-trade, tregti e brendshme-domestic trade (internal trade), tregti e jashtme-external trade (foreign trade), trehti e përgjithshme-general trade, tregti mallrashcommodity trade, tregti me pakicë-retail trade, tregti ndëkombëtare-international trade, tregti ndërkontinentaleintercontinental trade, tregti private-private trade, tregti veri-jug-north-south trade etc.

Notions in the field of finance: financa funksionale-functional finance, financa publike-public finances, financë strategjike-strategic finance, financim i brendshëm-internal financing, financim i ekportit-export financing, financim i nvestimeve-investment finance, financim i plotë-fully funded, financim me kredi-credit financing, financim nga shtetigovernment financing etc.

\section{Conclusion}

We notice that in the last decade there are also synonyms that are formed by the parallel use of the foreign term and Albanian term in economics and finance. Antonym pairs have also increased. The antonymy positively characterizes the terminology, since it verifies about the systemic connection of concepts, for an advanced terminology in the system. The semantic structures of these terms relate to new communication needs caused by the birth of new phenomenas and concepts. But, despite all the restrictions and changes in the structure of meaning, these terms, even in this period are multi-semantic because, besides their main understanding, they also have one or two other meanings.

The meticulous work that has been done for the processing of all this fund of terms in the field of economy and finance has had its effectiveness: refined terms that entered the textbooks (from the beginning of the 70s of XX c.) were adopted by whole generations of students-specialists in various fields of knowledge, and were used during the drafting of textbooks, projects and scientific works, and all the way to the press, in radio and television.

Groups of specialists and specialists in relevant fields need to take part in the construction of the economy and finance terminology, by providing relevant definitions in the terminological system.

The work for the standardization of the terminology of economy in Albanian language, except the national aspect, has also got the international aspect, which helps inform these achievements and communication also between specialists, of economy and finance, of different countries and who speak different languages.

Word borrowings in Both languages Can Be Viewed from Many Angles, soft theire Each language evidencing in 
taxes to first place and the attitude Which is Held tell about. The evidencing of borrowings, particularly in the English Language, by comparing with theire say equivalences in English, the bring out theire distinctions in the each language, which are conditioned by the time of the Forming of the economics terminology in the respective language.

\section{References}

A. Duro, "Studime gjuhësore (terminologji, gjuhësi kompjuterike, kritikë-bibliografi)", QSA IGJL, Tiranë, 2012.

"Banking terminology (Albanian-English-French-Italian-Russian)", Tirana, 2014.

Fjalor i termave të financës e të kontabilitetit, Tiranë, 1985.

G. Pllana,"Observations on antonyms in the field of thermo-technics" Accession Number: ICLMC2015C11, Source ICLMC 2015, Conference Article, 9-10 April Kyoto, Japan, IACSIT Press, Vol. 83. ISBN-13: 978-981-09-5266-2., Kyoto, Japan, 2015.

H. Gorani, : "Fjalor i termave dhe i shprehjeve ekonomike serbokroatisht-shqip", Prishtinë, 1986.

H. Gorani, "Probleme kuptimore të terminologjisë së ekonomisë", në Gjendja dhe zhvillimi i terminologjisë shqipe problem dhe detyra, Konferencë shkencore, ASHSH dhe ASHAK, Tiranë, 2009.

H. Pasho, "Terminologjia e ekonomisë në gjuhën shqipe (nga Rilindja deri në vitet '80 të shek. XX", ASHSH IGJL, Tiranë, 2005.

N. Rexha, "Fjalor i biznesit, ekonomikës dhe finances shqip-anglisht", ASAU, Prishtinë, 2009.

S. Pllana, "Leksiku terminologjik i ekonomisë-një fushë e veçantë e dijes", në Gjurmime albanologjike, IA Nr. 43/2013, Seria e shkencave filologjike, Prishtinë, 2014.

S. Pllana\&G. Pllana, "About some manifestations of antonymy and synonomy in the terminology of economics", 40 ICHS May 31-June 01, 2014 Budva-Montenegro, Conference Proceedings, MCSER Publishing-Rome, Italy, 2014. 